\title{
Anti-Corruption Education at Universitas Negeri Semarang: What Benefits Can Students Get?
}

\author{
Eko Handoyo \\ Associate Professor of Politics and Citizenship Department, Faculty of Social Sciences, Universitas \\ Negeri Semarang, eko.handoyo@ mail.unnes.ac.id. \\ ORCID : https://orcid.org/0000-0003-1953-8233.
}

\begin{abstract}
Corruption is the main problem faced by countries in the world. Corruption is considered an extraordinary crime; therefore, eradicating it also requires extraordinary action. Education is one way to reduce the potential for Corruption. This paper will discuss implementing anti-corruption education courses at the Universitas Negeri Semarang and the benefits of the Anti-Corruption Education (PAK) course for students. To achieve it, the research methods applied are quantitative and qualitative. Quantitative data were analyzed using descriptive statistics. While qualitative data were analyzed using qualitative analysis. The results showed that implementing anti-corruption education courses, starting from lesson planning, implementation to learning evaluation, had gone well. Students taking part in the lectures feel that there are benefits, including increased knowledge of anti-corruption and a commitment not to corrupt in either life inside the campus or outside the campus.
\end{abstract}

Keywords: Benefits, Learning, Anti-Corruption Education

\section{INTRODUCTION}

Indonesia has great potential to become a developed country with a high per capita income (Elias \& Noone, 2011; OECD, 2018). In the 2014-2018 period, the value of Indonesia's GDP at current prices showed a significant increase, namely 10,569,705.3 billion rupiah (2014); 11,526,332.8 billion rupiah (2015); $12,401,728.5$ billion rupiah (2016); 13,587,212.6 billion rupiah (2017) and 14,837,357.5 billion rupiah in 2018 (BPS, 2019). The changes influence the increasing value in both price and volume. The Central Statistics Agency (BPS) noted that Indonesia's per capita gross domestic product (GDP) increased to US\$ 3,927 or around IDR 56 million per capita per year in 2018 (Laucereno, 2019). It is an increase compared to the amount of IDR 51.9 million in 2017 and IDR 47.9 million in 2016.

The increase in Indonesia's national income will be meaningless if the corruptors are still undermining the country. ICW data shows that the amount of money stolen by corruptors, both from the legislative, executive, and judicial branches, has an average of IDR 4.17 trillion (Alamsyah, Wana, 2018). The data compiled by the Corruption Eradication Commission (KPK) surprisingly shows that the amount of money corrupted was Rp 168 trillion (Idhom, 2020). If not stolen, that much money can be used to build 195 elementary school buildings, finance 3.36 million people to study until graduating from college, repair $21,313 \mathrm{~km}$ of district roads and 2,468 $\mathrm{km}$ of damaged provincial roads, capitalize 33.6 million households to become entrepreneurs with the capital of IDR 5 million for each of them. Since the establishment of the KPK until 2013, most Corruption perpetrators were from the private sector, namely 44\% (KPK, 2018). During the Covid19 pandemic, Corruption still hit Indonesia. Several officials who the KPK has arrested for committing criminal acts of Corruption, including Saiful Ilah, the East Java regent, Wahyu Setiawan, the General Elections Commission (KPU) commissioner, Agustiani Tio Fridellina, member of the Elections Supervisory Agency (Bawaslu), Nurhadi, the former secretary of the Supreme Court (MA), Ismunandar, the East Kutai regent, Encek Unguria, the chairman of the East Kutai Regional Legislative Council (DPRD), Edhy Prabowo, the Minister of Marine Affairs and Fisheries, Ajay Muhammad Priatna, the mayor of Cimahi, Wenny Bukamo, the regent of Banggai Laut, Juliari P. Batubara, the Minister of Social Affairs of the Republic of Indonesia.

Several studies have shown that Corruption is related to GDP and even has some destructive force on sustainable development in many countries (Enste \& Heldman, 2017; Hoinaru, Razvan, 2020; Lucic et al., 2016). Many people hope that there is no corruption in their country. Likewise, the Indonesians hope for no corruption in the government so that they can achieve prosperity. However, this dream will be just a dream when there is no active participation from Indonesian citizens, including those involved in the Higher Education Institutions (Widiastuti, 2009). KPK's efforts to prevent and eradicate Corruption must be supported by all parties, including university campuses (Laksmana, Ganjar, 2015). By preparing a generation with integrity through anti-corruption education, people hope that there will be generations being proactive in thinking about 
their nation's fate rather than only thinking about themselves. Anti-corruption education implemented in universities plays an essential role in preventing Corruption (Ochse, 2004).

Anti-corruption education (PAK) as an independent lecture or inserted into related subjects and supported by student activities that instill integrity values in various universities has been carried out in recent years. Bandung Institut of Technology (ITB), Universitas Paramadhina, and Universitas Negeri Semarang (UNNES) have become pioneers in conducting PAK lectures mobilized massively for the recent years on other campuses.

Anti-corruption education is essential in universities because universities play a vital role in mobilizing anti-corruption movements and keeping students away from Corruption acts (Dirwan, 2016; Seto, 2019; Sarmini et al., 2018). Several studies have found a positive impact in the implementation of anti-corruption education, in which students increase their knowledge about Corruption and anti-corruption values as well as the growth of anti-corruption attitudes and commitments, prevent actions that damage and destroy themselves, the environment, and the country, and produce honest nation's children (Harto, 2014; Kristiono, 2018; Manurung, 2012).

This paper intends to answer the problems of (1) how the implementation of anti-corruption education courses at Universitas Negeri Semarang, especially in the Political Science study program, is and (2) what benefits students get from the Anti-Corruption Education course for students are.

\section{REVIEW OF LITERATURE}

\subsection{Corruption and its Eradication Strategy}

Defining Corruption is not easy because of the complexity of actions categorized as Corruption acts(Tanzi, 1998). As stated by Phil Williams, the increasing variety of Corruption is due to the perpetrators' sophistication, which causes the definition of Corruption to be continuously reviewed to obtain a systematic and complete understanding (Handoyo, 2013).

Corruption comes from the Latin corruptio or coruptus. Coruptio comes from the word corrumpere, an older Latin word (Cresswell, 2010; Priyono, 2018). From Latin, it has come down to many European languages such as English, namely Corruption and Dutch, which is corruptie, and from Dutch, the word has come down to Indonesian, namely korupsi. (Cresswell, 2010). In the Legal Dictionary (2002), Corruption is defined as evil deeds, damage, and likes to accept bribes, divert money or property belonging to companies or the state by using their position for personal gain (Handoyo, 2013). Corruption is an infectious activity that results in decay (Al Zadjali, 2010).

Corruption is the abuse of roles, public positions, or personal gain resources (Ikobi-Anyali, 2017; OECD, 2007; Rose, 2018). The term abuse (misuse) refers to behavior that deviates, either from formal official duties from the public role or against informal rules (which are built through public expectations or a standardized code of ethics) or, in general, narrow interests followed by public interest expenditures on a large and wide-scale (Handoyo, 2013). Corruption is also understood as behavior that deviates from a state office's official duties because of personal status or monetary benefits (individual, close family, own group) or violates the rules for implementing some personal behavior (Klitgaard, 2005). Corruption is also interpreted as a deviation from legally decided norms (Warren, 2004). Corruption occurs through a process of supply and demand related to payment or delivery of goods (Kurer, 2015). Corruption is like a steward and a purveyor (Rose, 2017).

The concept of Corruption has a broader scope, does not stop at the word Corruption. Priyono (2018) lists various acts categorized as Corruption acts, namely bribery, nepotism, collusion, state capture, patronage, conflicts of interest, money politics, plagiarism, fraud, gratification, poor sportsmanship, discrimination, professional fraud, and evidence fraud. In a broad sense, malpractice, misallocation, and adultery can also be included in Corruption.

Haller and Shore (2015) in (Agustino \& Fitriani, 2017) mention six forms of Corruption: bribery, embezzlement, fraud, extortion, nepotism, and other illegal acts that harm the state. These forms of Corruption can be found in almost all places in government (Morris, 2011). The countries most affected by Corruption are countries in Sub-Saharan Africa, Latin America, some newly industrialized countries, and some communist countries (Amundsen, 1999). 
In the legal context, Corruption has various forms of clear criminal sanctions as regulated in Law No. 31/ 1999 and has been amended by Law No. 20/ 2001. In the Corruption Law, the forms categorized as a criminal act of Corruption are Corruption related to state financial losses, bribery, embezzlement in office, extortion, fraudulent acts, conflict of interest, and gratuities (KPK, 2006).

Not all actions fall into the category of Corruption. Alatas in (Handoyo, 2013) describes the characteristics of an act which is said to be an act of Corruption, namely: (1) corruption always involves more than one person; (2) corruption generally involves confidentiality; (3) corruption involves elements of obligation and mutual benefit; (4) those who practice corrupt ways usually try to cover up their actions by taking cover behind legal justifications; (5) every act of Corruption contains fraud, usually in public bodies or the general public; (6) every form of Corruption is a betrayal of trust; (7) every form of Corruption involves a contradictory dual function; (8) an act of Corruption violates the norms of duties and responsibilities in the public order.

Corruption eradication is a series of actions to prevent and tackle Corruption (through coordination, supervision, monitoring, investigation, prosecution, and examination at court proceedings) with public participation based on the prevailing laws and regulations (KPK, 2006). Eradicating Corruption must be done because a corrupt government will find it hard to get funding for development (Rose-Ackerman, 2006). Successful efforts in eradicating Corruption will affect the welfare of the population because the funds that are not corrupted can be used to repair roads, build reservoirs, build toll roads, and build housing, all of which are beneficial for the welfare of the people (Mariyono, 2012). Conversely, suppose the eradication of Corruption is not successful. In that case, it can cause the nation's development to fail, and in turn, efforts to reduce poverty and improve the welfare of the community will be disrupted (Guney, 2014; Hoinaru et al., 2020).

Efforts to eradicate Corruption can be carried out in three ways, namely: (1) prevention, (2) repression, and (3) community participation. In Indonesia, efforts to eradicate Corruption have been taken seriously, primarily through law enforcement. Law enforcement agencies such as the police, prosecutors, and courts have worked hard to work towards this. However, corruption activities are still ongoing today. Curative efforts have produced immediate results and have had such deterrent effect, however because of the broad spectrum of corrupt behavior, and other efforts are needed, although the results cannot be seen now, namely through anti-corruption education (Puspito, Nanang T., 2011).

\subsection{Anti-Corruption Values}

Anti-corruption is a policy to prevent and eliminate opportunities for the development of Corruption. Prevention means how to raise individual awareness not to commit Corruption and how to save money and state assets (Handoyo, 2013). Corruption prevention is carried out through education at both the primary and secondary and higher education levels (Fajar \& Muriman, 2018). Education for young children is also needed to build a culture of integrity (OECD, n.d.).

Pope in(Handoyo, 2013) suggests that for the anti-corruption efforts can be successful, it is necessary to have: (1) a strong will on the part of the political leadership to eradicate Corruption wherever it occurs and to be examined; (2) emphasizes preventing future Corruption and improving the system; (3) adaptation of anticorruption laws that are comprehensive and enforced by institutions that have integrity; (4) identification of government activities that are most prone to inciting Corruption and reviewing relevant laws and administrative procedures; (5) programs to ensure that salaries for civil servants and political leaders reflect their respective job responsibilities and are not significantly different from salaries in the private sector; (6) research on legal and administrative improvement efforts that ensure that the legal and administrative measures concerned are sufficiently capable of functioning as a base of Corruption; (7) creating partnerships between government and civil society; (8) making Corruption a high-risk and low-profit act; (9) developing an ever-changing management style that minimizes the risk for people involved in "petty" corruption, and who has the support of political figures, but is seen by the broader public as a fair and sensible program for the situation there is.

Anti-corruption values that guide the implementation of anti-corruption education include honesty, care, independence, discipline, responsibility, hard work, simplicity, courage, and justice (Rosikah dan Dessy Marliani Listianingsih, 2016). These anti-corruption values need to be instilled in the younger generation, especially students, because students are candidates for future national leaders who will contribute to determining their direction.

\subsection{Anti-corruption Education in Higher Education Institutions}

Anti-corruption education needs to be implemented in higher-ed institutions because several surveys have found that universities have become a hotbed of Corruption since the higher education industry has rapidly 
grown (Osipian, 2008; Osipian, 2007; Orkodashvili, 2010). In a book authored by Kirya (2019) about Corruption in Universities: Paths to Integrity in the Higher Education Subsector, the potential for Corruption in higher education has been identified, including in managing the accreditation of study programs or institutions, selection of prospective students, recruitment and promotion of staff, and budget management in procurement.

Anti-corruption education has been implemented in various countries, either in mainland Europe, Africa, Asia, America, or Australia. In the world, a collaborative network between countries has also been formed to introduce anti-corruption education programs. One example of anti-corruption education is what has been implemented by China. ThroughChina onLine, all students at the primary education level are given anticorruption education courses to provide students a vaccine against the dangers of Corruption. (Handoyo, 2013). In the long term, China's young generation can protect themselves amid the onslaught of the influence of corruption crimes.

Higher education has such an important role in instilling anti-corruption values in students. More than that, universities also play a role in maintaining campus residents' integrity so that they work for the benefit of society, nation, and state. Higher education is not only the guardian and developer of the nation's integrity or as part of the anti-corruption movement, but higher education can also be a milestone for the development of accountability and transparency as well as a driving force for integrity capable of playing an essential role in stopping the"supply" of corrupt officials in this country (Kadir, 2018).

The implementation of anti-corruption education in higher education is strengthened by the publication of Circular Letter of Directorate General of Higher Education(Dirjen Dikti) No. 1016/E/T/2012 about the Implementation of Higher Education Anti-Corruption Education. The circular, which is addressed to all higher education leaders, calls on higher education leaders to organize anti-corruption education from the 2012/2013 academic year in compulsory or elective courses or inserted into relevant courses.

The Directorate General of Learning and Student Affairs of National Research and Innovation Agency (Ristekdikti) during the PAK National Coordination Meeting on December 11, 2018, gave higher education leaders direction to become the spearhead of corruption eradication through anti-corruption education (Ismunandar, 2018). Therefore, higher education institutions must educate students to become future leaders of the nation with strong social responsibility. In line with these goals, it is called for (1) anti-corruption education on campus to become the spearhead of the corruption eradication plan, (2) encourage changes in ways, patterns of thought, attitudes, moral commitment, enthusiasm for progress, high achievement, productive, love for the country, respect multiculturalism, and be anti-corruption in students so that students are ready to compete and excel in the global arena.

\section{RESEARCH METHOD}

This paper is based on quantitative research methods, especially on descriptive statistics. This descriptive research is a research method to describe and interpret objects as what they are (Sukardi, 2004). This research also uses qualitative methods. The quantitative method is used to answer the first research question: how to conduct Anti-Corruption Education courses at Universitas Negeri Semarang. The first-research formulation indicators include planning, implementation, and evaluation of learning.

The study population was the participants from two classes of the Anti-Corruption Education (PAK) course in the Political Science study program, majoring in Politics and Citizenship, Faculty of Social Sciences, Universitas Negeri Semarang. There are 100 students of the Anticorruption Education 2019 course divided into two classes, each containing 50 students. Random sampling is done (Sedarmayanti, 2011), and from the population, as many as 50 people or $50 \%$ were taken.

Data were collected using instruments in the form of questionnaires and interview guidelines. Data were analyzed quantitatively with descriptive statistics. The statistical tool used is the statistic to measure the main symptom using the calculated mean (Sedarmayanti, 2011). The statistical analysis was used to answer the first research problem, namely how to conduct Anti-Corruption Education courses at UNNES. Meanwhile, to answer the second research question, namely what benefits that students get from the Anti-Corruption Education course for students are, qualitative analysis with a spiral data analysis model from Creswell is used which startedfrom data management, reading and making memos, describing, clarifying, and interpreting data into codes and themes, interpreting data, and ends with presenting and visualizing the data (Creswell, 2015).

\section{RESULTS}

\subsection{The Implementation of PAK Lectures}

The data collected regarding the implementation of PAK courses include planning, implementing, and evaluation of learning. The planning consists of preparing semester lesson plans (RPS), planning learning assignments, and preparing learning resources (lecture references). The implementation of lectures includes 
applying learning scenarios, delivery of learning materials, mastery of learning materials, applying learning methods, using learning media, using e-learning, implementing learning assistance, and providing learning motivation. Besides, in lectures' performance, the lecturers' attitudes during learning activities, the discipline of lecturers in lecturing activities, the lecturers' voice, student understanding of the material presented by the lecturers, and anti-corruption values taught by the lecturers were also examined. The lecture evaluation includes the implementation of midterm and final semester exams. Apart from planning, implementing, and evaluating lectures, this research also examines PAK courses' teaching requirements.

In planning lectures, most lecturers (84\%) have compiled RPS and uploaded it to the UNNES educational system via the apps.unnes.ac.id page. The data on the number of lecturers who uploaded the RPS before the lecture was as follows.

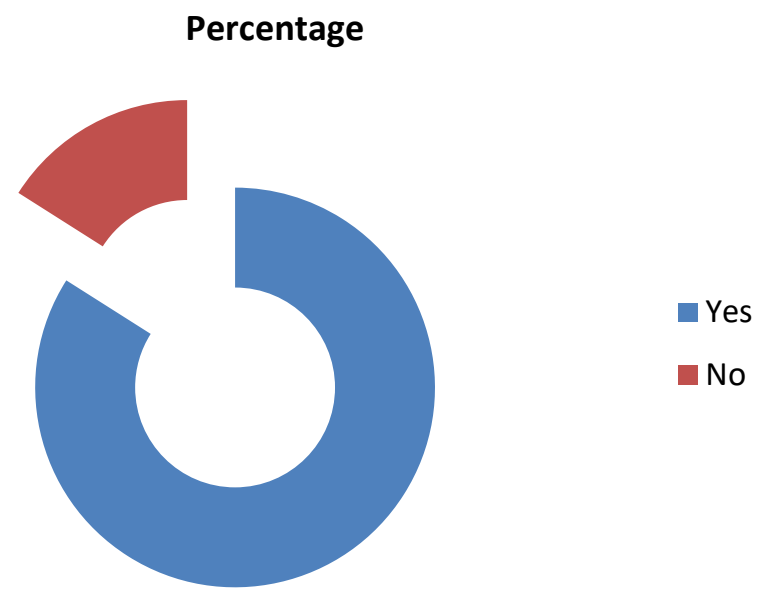

FIGURE 1. Lecturer uploading and submitting RPS at the beginning of the lecture

Lecturers who teach the PAK course before lecturing has planned their course assignments well. However, by most students, lecture assignments are seen as too burdensome. The burdensome task is to make anthems on the concept of Corruption and to hold an anti-corruption festival. The data on the number of students who feel that the lecture assignment is burdensome is as follows.

\section{Percentage}
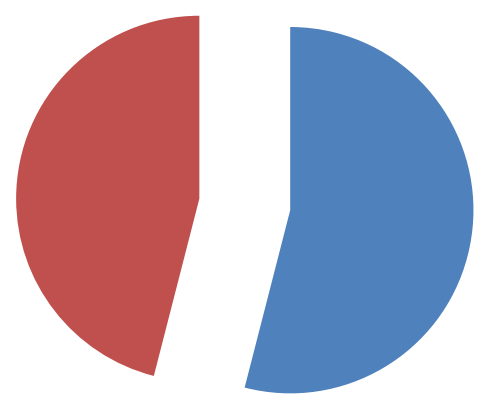

Incriminating task

The task is not

burdensome

FIGURE 2. Students' Views of Class Assignments

In terms of lecture references, most lecturers have designed lecture references properly. For students, the references or sourcebooks provided are quite adequate. As many as 38 respondents, or $76 \%$, stated that sufficient reference books were available. However, as many as 12 respondents, or 24\%, stated that it was not enough, wanted the latest books to study corruption cases, and knew effective ways of dealing with Corruption. 


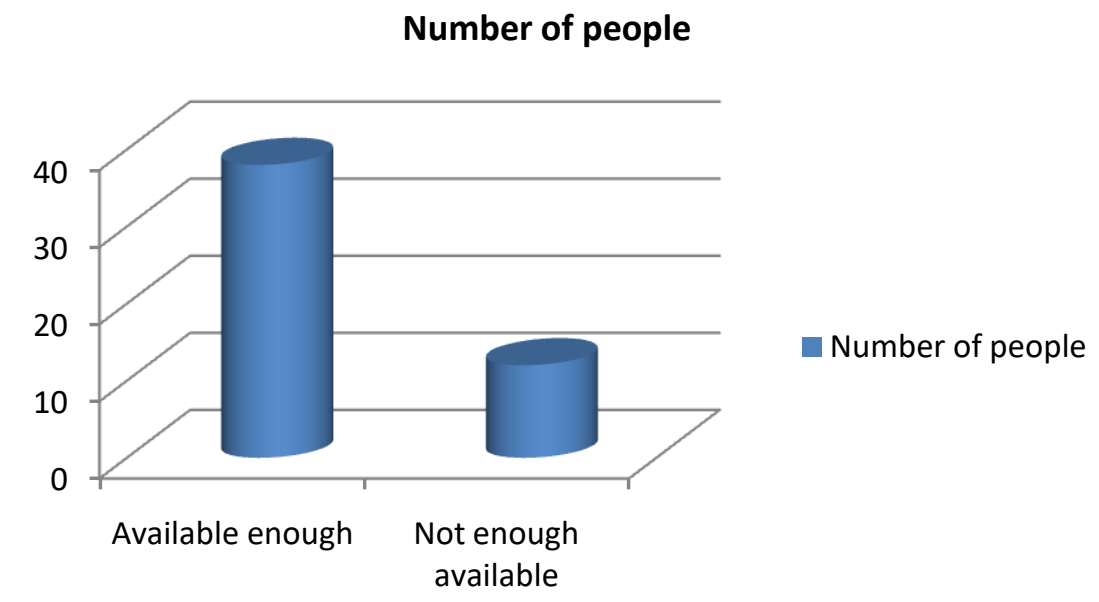

FIGURE 3. Student opinion about the availability of Reference Books

By the designed RPS, the learning scenario applied by the lecturer is good. Most of the lecturers (82\%) have implemented the learning scenario according to the prepared RPS. The complete data can be seen in the following figure.

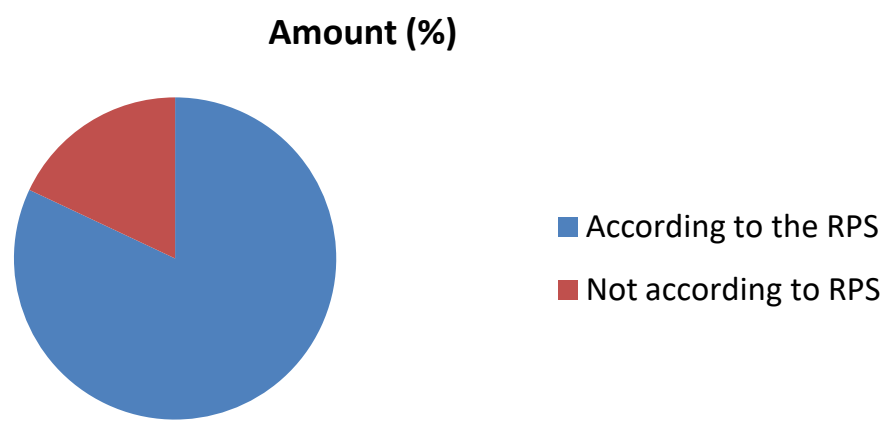

FIGURE 4. Lecturer Learning Scenarios

Learning activities are said to be good if they are carried out under the prepared learning plan. Most of the PAK lecturers $(86 \%)$ have carried out the activities well. The learning material presented has been following the RPS.

\section{Amount (\%)}

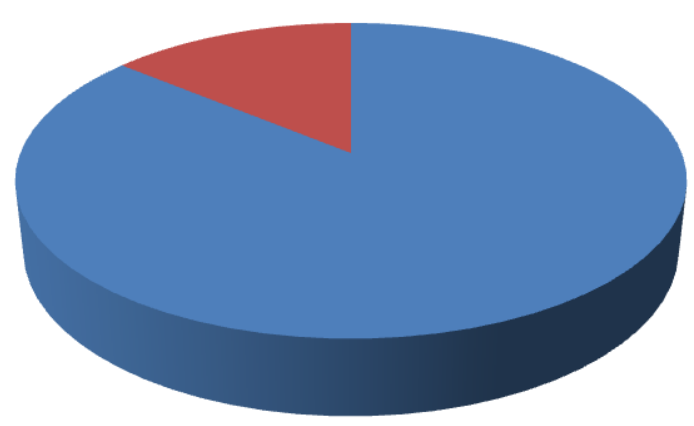

In accordance with RPS

Not according to RPS

FIGURE 5. Compatibility of Learning Materials with RPS 
Excellent and qualified lecturers are lecturers who master the learning material because mastery of learning materials will make it easier for students to receive the lecturer's learning material (Yang Pan \& Owen, 2013). All lecturers who teach the PAK course have mastered the learning material. Here are the data.

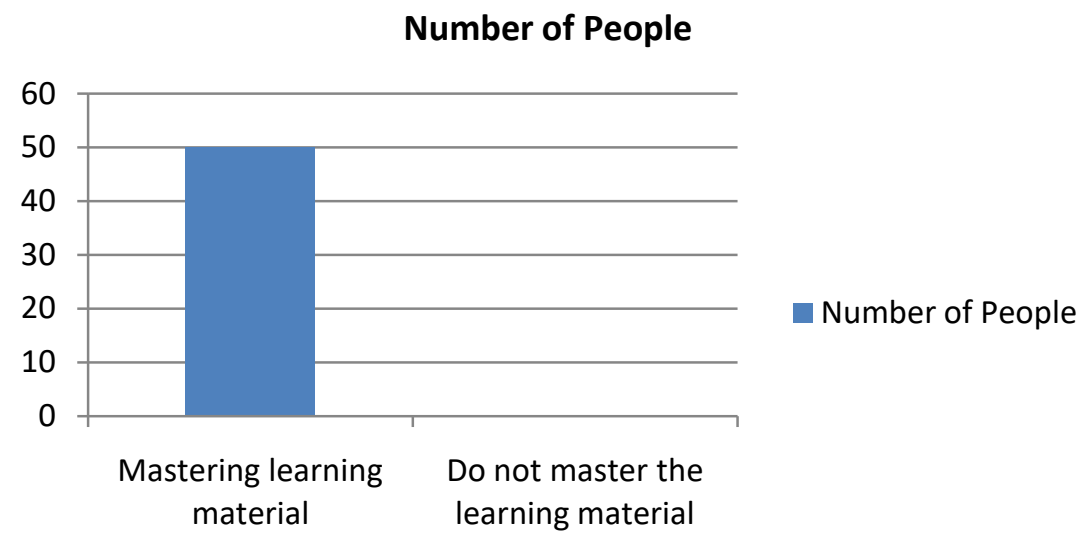

FIGURE 6. Number of Lecturers who master the learning material

Under the National Education Standards, learning carried out in universities uses the Student-Centered Learning approach or abbreviated as SCL (Junaidi, Aris, 2020). By the SCL approach, the learning forms and methods chosen must be attractive, allowing students to have freedom and independence when participating in learning activities. The questionnaire data shows that the lecturers' learning methods are in accordance with the RPS and are attractive to students.

\section{Percentage (\%)}

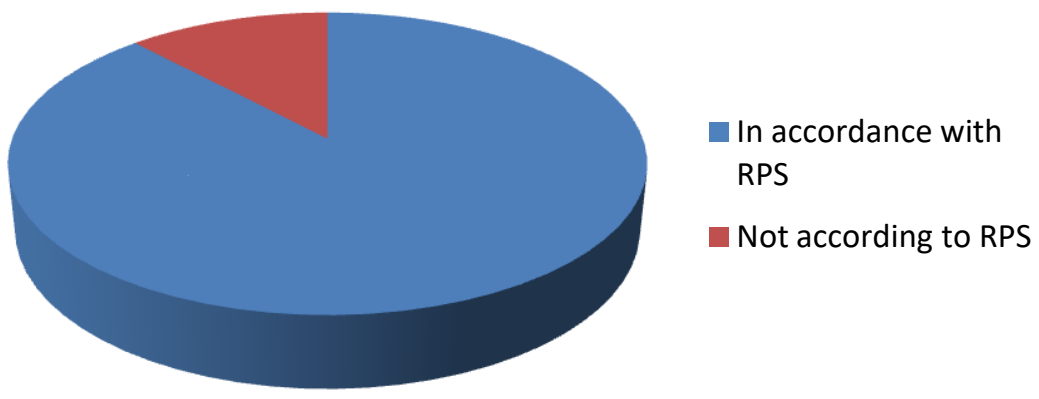

FIGURE 7. Conformity of Learning Method with RPS

However, it was also found that some lecturers were teaching primarily using the lecture method. Many students said that the lecture method was tedious and did not provide any motivation to learn.

In addition to the chosen learning method, learning media also determines the success of learning. Most of the PAK lecturers have used learning media that are attractive to students. Here are the data. 


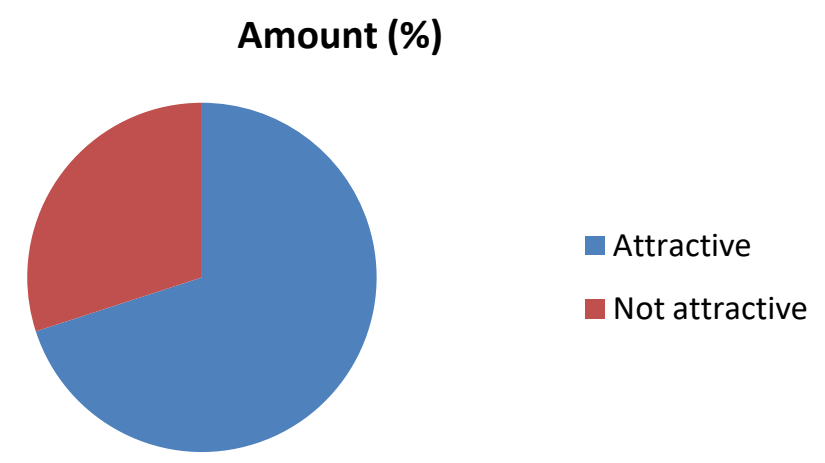

FIGURE 8. The Winning of Learning Media

The learning media used mainly by lecturers in teaching PAK are videos/films. Next is Elena (a web-based Learning Management system managed by UNNES), PowerPoint, and games. The complete data can be seen in the following figure.

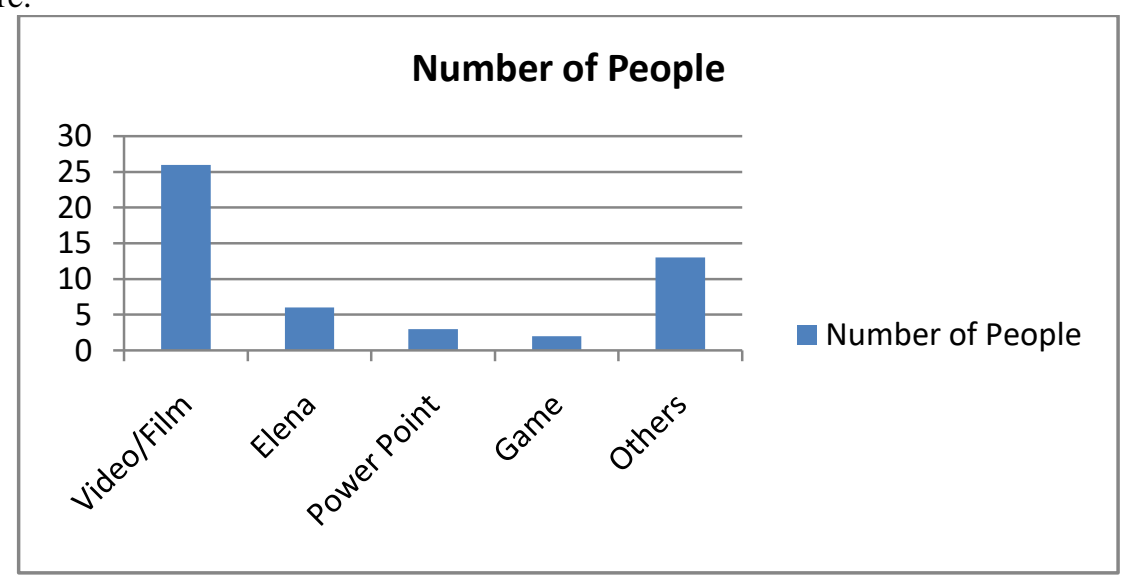

FIGURE 9. Number of Lecturers using innovative learning media

In the era of the industrial revolution 4.0, learning activities were no longer dominated by physical or faceto-face activities between lecturers and students in the class. Learning resources are not entirely one-way from the lecturers, but learning in the 21 st century has already been based on data and technology. The questionnaire results showed that as many as $66 \%$ of the lecturers carried out electronic learning using Elena, the web-based Learning Management system managed by UNNES. However, some students (12\%) admitted that e-learning was quite burdensome. The reasons presented are various, such as electronic learning requires WiFi that is ready or connected to the internet, not all lecturers understand electronic learning at Elena, too many assignments that must be downloaded from Elena's page task of making videos that must be uploaded on Elena.

Not all students have the same abilities in following the lessons. Therefore, lecturers assist students who experience difficulties in learning. The form of assistance is in accessing learning resources, how to use Elena, and others.

The evaluation of learning in the Anti-Corruption Education course can be seen from how the midterm and final semester exams are implemented. Mid-semester exams (UTS) have been carried out following the RPS, where 46 respondents, or $92 \%$, stated that the UTS was following the RPS, while the other 4 or $8 \%$ said they were not. Most students want the UTS done at home, and the form can be multiple choice questions or essay questions. If the assessments are replaced in papers or research reports, they hope that the assignment will not burden students. The final semester exams, which have been carried out in the form of essay questions, are not a problem for students, but they suggest a way applied so far, namely that students can do it in the form of an open book exam be maintained. The following is visual data about the relevance of UTS to RPS. 


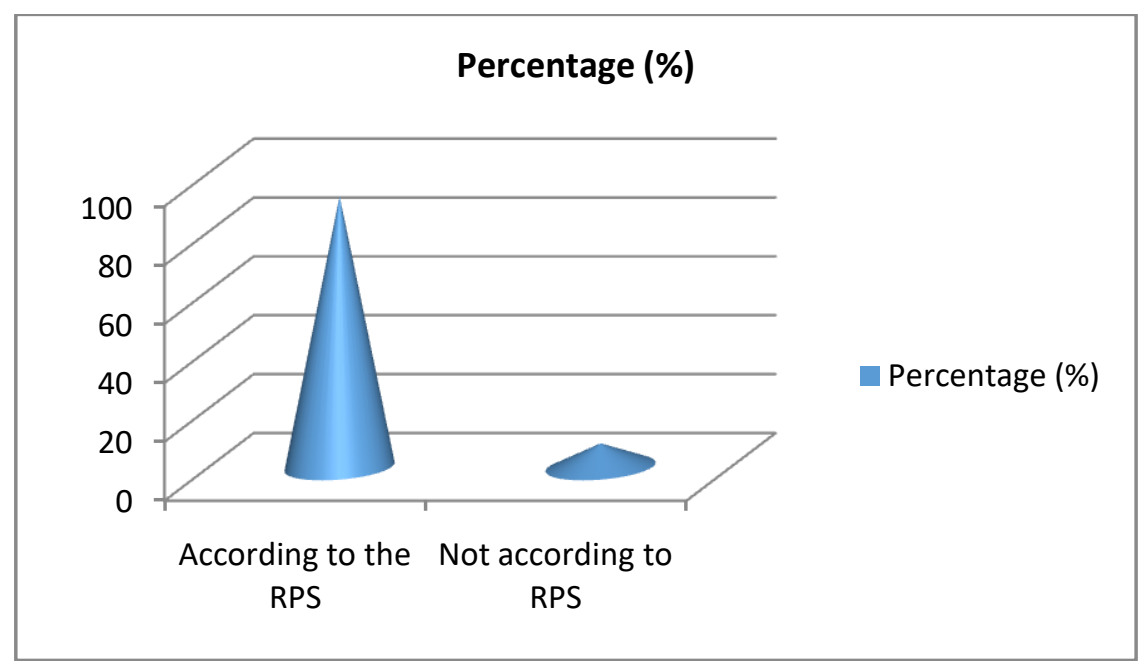

FIGURE 10. Suitability of Midterm Exams with RPS

\subsection{The Benefits of PAK Lectures}

Data on the benefits of PAK courses were compiled from questionnaires and interview guides filled out by students. The results show that the course has given some benefits for students. All respondents interviewed, namely, 50 students or $100 \%$, answered that the PAK course provided tangible benefits.

\section{Number of People}

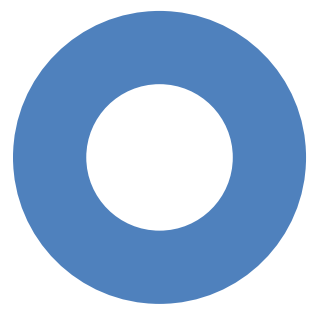

PAK is useful

PAK is not useful

FIGURE 11. Number of students who declare PAK useful

Regarding the benefits of the Anti-Corruption Education course, here are some testimonials from the respondents interviewed.

"For me, the benefit of anti-corruption education is that I gain knowledge about corruption and how to combat it" (Interview with Cantika, 1December 2020).

"After studying the Anti-Corruption Education course, I understand more and more that corruption is very detrimental to society, the nation and the state, therefore I will be careful not to commit acts of corruption and encourage people in the neighborhood not to do corruption" (Interview with Ica, 1 December 2020).

"After taking the Anti-Corruption Education course, I will no longer waste cheating like I have done while taking other courses" (Interview with Salsha, 5 January 2021). The benefits of joining the AntiCorruption Education are (1) providing sufficient knowledge about the ins and outs of Corruption, (2) how to eradicate Corruption, and (3) how to instill anti-corruption values in the younger generation. Therefore, I am committed to being anti-corruption wherever I am (Interview with Eva, 2 December 2020). 
From the interviews conducted, information was obtained that the benefits received by students during and after graduating from the PAK course were: (1) students became more disciplined, (2) students had a better understanding of the meaning of Corruption, (3) students knew the impact of Corruption, (4) students were more self-introspective, (5) students could respect their time, (6) students knew anti-corruption attitudes, (7) students avoided being corrupt, (8) PAK taught the meaning of honesty to students, (9) PAK instilled student awareness to act honestly or more honestly, (10) students knew that Corruption is a detrimental act, (12) students could restrain themselves, (13) students were motivated not to commit any corruption, and (14) students were taught to avoid any corrupt behavior. Although this is still in the awareness and attitude stage and has not shown evidence of not committing Corruption, this fact indicates that students commit not to corrupt when they graduate.

From the questionnaire data and the interviews results, it can be concluded that the benefits of the PAK course can be categorized into two, namely cognitive benefits and affective benefits. The cognitive benefits are increasing understanding of the concepts of Corruption and anti-corruption. In contrast, the affective benefit is instilling an anti-corruption attitude and motivating students not to commit any Corruption acts on campus and off-campus activities.

\section{DISCUSSION and CONCLUSIONS}

\subsection{Discussion}

In the Corruption Eradication Law No. 31/ 1999, it is stated that the public can play a role and assist in efforts to prevent and eradicate Corruption. This role can be realized in seeking, obtaining, and providing information on Corruption's suspicions, providing information on Corruption allegations to law enforcers handling corruption cases, and conveying responsible suggestions and opinions to law enforcers who handle corruption cases. In short, the public has the right and responsibility in efforts to prevent and eradicate Corruption. In many countries, this role is usually played by civil society organizations (Ralchev, 2004). Civil society primarily plays a role in providing checks and balances to improve public and private accountability (UNODC, 2019). Civil society promotes transparency and accountability to improve the political system through anti-corruption efforts (Ukase \& Audu, 2015).

In Indonesia, the participation of the community is in line with the KPK duties as stipulated in Law No. 30/ 2002 concerning the Corruption Eradication Commission (KPK), namely coordination with agencies authorized to eradicate corruption crimes; supervision of agencies authorized to eliminate criminal acts of Corruption; carrying out a preliminary investigation, full investigation, and prosecutions of criminal acts of Corruption; taking actions to prevent criminal acts of Corruption; and, monitoring the implementation of state governance. If they are summarized, the KPK's duties are twofold: eradicating Corruption and preventing Corruption. The role of the community is more related to the task of the KPK in preventing Corruption.

One of the efforts to prevent Corruption is to implement anti-corruption education through anti-corruption lessons in tertiary institutions (Sarmini et al., 2017). In this regard, many universities have implemented AntiCorruption Education, either in separate courses, anti-corruption material inserted into other courses, or even in student activities with anti-corruption content. The inculcation of anti-corruption values through education is considered appropriate because, through education, students can absorb knowledge and internalize anticorruption values properly. Education will also educate the public about corruption crimes and provide further encouragement to fight Corruption (Marquette, 2006).

In the anti-corruption learning activities carried out in the Anti-Corruption Education course, the university has prepared lecturers to have the competence to teach the Anti-corruption Education course. In Indonesia, most of the lecturers who teach these courses are competent because they have been trained by the KPK and the Directorate General of Higher Education. The lecturers have also taken the competency test as an anti-corruption instructor, legalized by the KPK.

Furthermore, the lecturers deliver anti-corruption material both inside and outside the classroom to educate students to master the course's learning outcomes and equip them to care about the fate of their nation and country. The lecturers' mastery of learning materials and learning methods depends on the lecturers' educational background, teaching experience, and anti-corruption training that has been attended.

Before teaching, the lecturer conducts lesson planning. This planning is important because it will make it easier for lecturers to carry out the learning. AsSaputra \& Nasrudin (2015)research results that as facilitators and motivators, lecturers are required to plan the lessons well. However, no matter how well the lecturer prepares the learning design, if the implementation is not implemented correctly, it will not realize the learning outcomes planned in the RPS. The proverb says: "man behind the gun," which means that the lecturer is a subject who is seen as having a significant role in implementing the curriculum, including in carrying out learning activities in the classroom. 
The results showed that most of the lecturers who taught PAK courses had met the requirements as PAK lecturers and had the required competencies in designing and implementing learning activities. Lecturers who teach PAK in the Political Science study program have planned, implemented, and evaluated learning. Student responses to learning activities facilitated by lecturers are classified as good. Students feel some benefits are obtained during lectures, namely in addition to increasing knowledge about anti-corruption. There is also a commitment and awareness not to commit Corruption in life on campus or later in the community. Anticorruption knowledge and understanding are needed because they are fundamental factors that enable students to behave and act against Corruption.

Through anti-corruption education, it is hoped that students can become anti-corruption agents who have not only high competence but also a moral commitment (Mukti, 2018). Students' role is eagerly awaited because students are also the agents of change who can transform Indonesia from a country with a high corruption burden to a country with a low level of Corruption (Alfaqi et al., 2017; Widhiyaastuti \& Ariawan, 2018). Students as a generation who are IT literate and have high ideals are the primary capital for creating Indonesia's anticorruption generation in the future. This is important because a culture fosters acts of Corruption that the public does not consider as Corruption, namely gratification. According to Law Number 20 of 2001, gratification is a gift in a broad sense, which includes the provision of money, goods, rebates, commissions, interest-free loans, travel tickets, lodging facilities, travel tours, free medical treatment, and other facilities (Komisi Pemberantasan Korupsi, 2015; Andarnuswari, 2019). This gratuity can turn into a bribe when the recipient is a civil servant associated with his position (Andarnuswari, 2019b). Gratification or giving is considered a noble culture to maintain ties between individuals or between individuals and social groups in society. If allowed to continue, gratification will hold the recipient's attitude and actions hostage, encouraging broader Corruption. The permissive attitude of society towards gratification and respect for people who give gratification will make it difficult for the Indonesian nation to change this negative behavior, and gradually students as the younger generation will consider this behavior as a standard action and need to be maintained (Mita Argiya, 2013). This is where the importance of Anti-Corruption Education is given massively to students, the agents of change in the future, so they are not trapped in the wrong community mindset about gratification.

\subsection{Conclusion}

The research results show that (1) in anti-corruption education learning activities, each learning planning, learning implementation, and learning evaluation has gone well. Implementation of learning, which includes uploading RPS, availability of sourcebooks, learning scenarios, the suitability of learning materials, use of learning media, the attractiveness of learning media, variety of learning methods, and implementation of midterm exams, reaches an average percentage of 84.75\%; and (2) all respondents (100\%) stated that AntiCorruption Education learning was beneficial for students both cognitively and affectively.

This research implies that education is a strategic way to produce anti-corruption agents who play an essential role in preventing Corruption because education offers various ways to instill anti-corruption values that students then construct as personal and social values that guide them in their attitudes and actions on corruption issues.

\section{ACKNOWLEDGEMENTS}

The authors would like to thank the students who participated in this research and Tan Agung, who translated and corrected this manuscript.

\section{CONFLICT OF INTEREST}

No conflict of interest

\section{REFERENCES}

1. Agustino, L., \& Fitriani, E. (2017). Korupsi: Akar, Aktor, dan Locus. Pustaka Pelajar.

2. Al Zadjali, M. K. S. (2010). The Nature, Causes, Consequences, and Mitigation of Corruption: A New Paradigm and Role for Accounting. Thesis. https://core.ac.uk/download/pdf/35464373.pdf

3. Alamsyah, Wana, D. (2018). Laporan Tren Penindakan Kasus Korupsi Tahun 2018. ICW.

4. Alfaqi, M. Z., Habibi, M. M., \& Rapita, D. D. (2017). Peran Pemuda Dalam Upaya Pencegahan Korupsi dan Implikasinya Terhadap Ketahanan Wilayah. JURNAL KETAHANAN NASIONAL, 23(3), 320-337. 
5. Amundsen, I. (1999). Political Corruption: An Introduction to the Issues (WP 1999: 7). https://www.cmi.no/publications/file/1040-political-corruption.pdf

6. Andarnuswari, N. D. (ed). (2019a). Gratifikasi dalam Perspektif Agama. Komisi Pemberantasan Korupsi Republik Indonesia. https://aclc.kpk.go.id/wp-content/uploads/2020/04/Buku-Gratifikasidalam-Perspektif-Agama-final.pdf

7. Andarnuswari, N. D. (ed). (2019b). Kajian Implementasi Pasal Gratifikasi Dalam Putusan Pengadilan (Edisi Revisi). Komisi Pemberantasan Korupsi Republik Indonesia. https://aclc.kpk.go.id/wpcontent/uploads/2020/04/Buku-Kajian-Implementasi-Pasal-Gratifikasi-KPK2019-LowRes08052020.pdf

8. BPS. (2019). Produk Domestik Bruto Indonesia Menurut Pengeluaran 2014-2018. BPS.

9. Cresswell, J. (2010). Oxford Dictionary of Word Origins. Oxford University Press. https://doi.org/10.1093/acref/ 9780199547920.001.0001.

10. Creswell, J. W. (2015). Penelitian Kualitatif\&Desain Riset Memilih Diantara Lima Pendekatan. Pustaka Pelajar.

11. Dirwan, A. (2016). The Effect of Education against Corruption In Indonesia.

12. Elias, S., \& Noone, C. (2011). The Growth and Development of the Indonesian Economy. Reverse Bank of Australia. Bulletin, December Quarter 2011, 33-44. https://www.rba.gov.au/publications/bulletin/2011/dec/pdf/bu-1211-4.pdf

13. Enste, D., \& Heldman, C. (2017). Causes and consequences of Corruption: An overview of empirical results. Research Report.

14. Fajar, A., \& Muriman, C. (2018). Prevention of Corruption through Anti-Corruption Education. Advances in Social Science, Education and Humanities Research, Volume 251. Annual Civic Education Conference (ACEC 2018)., 650-653.

15. Guney, T. (2014). Corruption, Prosperity and Sustainable Development: Some New Evidence. ARALIK, 9(3), 181-206.

16. Handoyo, E. (2013). Pendidikan Anti Korupsi Edisi Revisi. Penerbit Ombak.

17. Harto, K. (2014). Pendidikan Anti Korupsi berbasis Agama. Intizar, Vol. 20(No.1), hlm. 121-138.

18. Hoinaru, Razvan, et al. (2020). The Impact of Corruption and Shadow Economy on the Economic and Sustainable Development. Do They "Sand the Wheels" or "Grease the Wheels"? Sustainability, 12(481), 1-27.

19. Hoinaru, R., Buda, D., Borlea, S. N., Ligia, V., \& Achim, M. V. (2020). The Impact of Corruption and Shadow Economy on the Economic and Sustainable Development. Do They " Sand the Wheels " or " Grease the Wheels "? Sustainability, 12(2), 1-27.

20. Idhom, A. M. (2020). Akibat Korupsi, Uang Negara Menguap Rp168,19 triliun. Tempo.Com. https://nasional.tempo.co/read/464996/akibat-korupsi-uang-negara-menguap-rp16819triliun/full\&view $=$ ok

21. Ikobi-Anyali, A. L. (2017). Corruption and the Misuse of Public Office in the Commonwealth: The Preventive Role of Law Teachers in Nigeria and South Africa. Journal of Commonwealth Law and Legal Education, 12(1), 1-15.

22. Ismunandar. (2018). Pendidikan Tinggi: Reaktualisasi Pendidikan Anti Korupsi/Karakter/Moral untuk mewujudkan Indonesia Bebas Korupsi.

23. Junaidi, Aris, D. (2020). Panduan Penyusunan Kurikulum Pendidikan Tinggi di Era Industri 4.0 Untuk Mendukung Merdeka Belajar Kampus Merdeka. Direktorat Jnederal Pendidikan Tinggi, Kementerian Pendidikan dan Kebudayaan.

24. Kadir, Y. (2018). Kebijakan Pendidikan Anti Korupsi di Perguruan Tinggi. Gorontalo Law Review, 1(1, April), 25-38.

25. Kirya, M. (2019). Corruption in universities: Paths to integrity in the higher education subsector. CMI.

26. Komisi Pemberantasan Korupsi. (2015). Pengendalian Gratifikasi. https://aclc.kpk.go.id/wpcontent/uploads/2018/07/Pedoman_Pengendalian_Gratifikasi.pdf

27. KPK. (2006). Memahami untuk Membasmi (kedua). Komisi Pemberantasan Korupsi. 
28. KPK. (2018). Laporan Tahunan 2017 Demi Indonesia untuk Indonesia. Komisi Pemberantasan Korupsi.

29. Kristiono, N. (2018). Penanaman Nilai Antikorupsi bagi mahasiswa FIS UNNES melalui matakuliah Pendidikan Anti Korupsi. Refleksi Edukatika: Jurnal Ilmu Kependidikan, 9(1, Desember), 40-45.

30. Kurer, O. (2015). Definitions of Corruption. Routledge Handbook of Political Corruption, 48, 636. https://doi.org/10.4324/9781315739175.ch2

31. Laksmana, Ganjar, dkk. (2015). Laporan Tim Pengkajian Hukum tentang Partisipasi Aktif Publik dalam Pencegahan dan Pemberantasan Korupsi. BPHN, Kemenkumham RI.

32. Laucereno, S. F. (2019). Pendapatan Perkapita RI naik Jadi Rp56 juta per Tahun.

33. Lucic, D., Radisic, M., \& Dobromirov, D. (2016). Causality between Corruption and the level of GDP. Economic Researc H-Ekonomska Istraživanja, 29(1), 360-379.

34. Manurung, R. T. (2012). Pendidikan Antikorupsi sebagai Satuan Pembelajaran Berkarakter dan Humanistik. Jurnal Sosioteknologi, Edisi 27(Tahun 11), 232-244.

35. Mariam, O. (2010). Corruption in higher education: causes, consequences, reforms - the case of Georgia (No. 27679; Issue 10 August).

36. Mariyono, J. (2012). Corruption and Welfare: A Simple Econometric Across Countries Analysis. Economic Journal of Emerging Markets, 4(1), 63-75.

37. Marquette, H. (2006). Civic Education for Combating Corruption: Prospects for Donor-Funded Strategies.

38. Mita Argiya, V. S. P. (2013). Mengupas Tuntas Budaya Korupsi Yang Mengakar Serta Pembasmian Mafia Koruptor Menuju Indonesia Bersih. Recidive, 2(2), 162-170.

39. Morris, S. D. (2011). Forms of Corruption. CESifo DICE Report 2/2011.

40. Mukti, T. A. (2018). Mendorong Penerapan Pendidikan Anti Korupsi di Perguruan Tinggi. Perspektif Hukum, 18(2), 328-346.

41. Ochse, K. L. (2004). Preventing Corruption in the Education System A Practical Guide. Deutsche Gesellschaft für Technische Zusammenarbeit (GTZ) Gmb.

42. OECD. (n.d.). Education for IntegrityTeaching on Anti-Corruption, Values and the Rule of Law. https://www.oecd.org/governance/ethics/education-for-integrity-web.pdf

43. OECD. (2007). Corruption A Glossary of International Criminal Standards. https://www.oecd.org/daf/anti-bribery/corruptionglossaryofinternationalcriminalstandards.htm

44. OECD. (2018). OECD Economic Surveys: Indonesia 2018 (Issue October). https://www.google.com/search?ie=utf-8\&oe=utf-8\&cso=1\&q=OECD+Economic+SurveysIndonesia

45. Osipian, A. L. (2007). Corruption in Higher Education :2(4), 313-332.

46. Osipian, A. L. (2008). Corruption in Higher Education: does it differ across the nations and why? Research in Comparative and International Education, 3(4), 345-365.

47. Priyono, B. H. (2018). KORUPSI Melacak Arti, Menyimak Implikasi (pertama). PT. Gramedia Pustaka Utama.

48. Puspito, Nanang T., et al. (2011). Pendidikan Anti-Korupsi untuk Perguruan Tinggi. Kementerian Pendidikan dan Kebudayaan RI.

49. Ralchev, P. (2004). The Role of Civil Society in Fighting Corruption and Organized Crime in Southeast Europe. Southeast European and Black Sea Studies, 4(2), 325-331. https://doi.org/10.1080/1468385042000247600

50. Rose-Ackerman, S. (2006). International Handbook of the Economics of Corruption. Edward Elgar Publishing Limited.

51. Rose, J. (2017). The Meaning of Corruption: Testing the Coherence and Adequacy of Corruption Definitions The Meaning of Corruption: Testing the Coherence and Adequacy of Corruption Definitions. Public Integrity, O(0), 1-14. https://doi.org/10.1080/10999922.2017.1397999

52. Rose, J. (2018). The Meaning of Corruption: Testing the Coherence and Adequacy of Corruption Definitions. Public Integrity, 20(3), 220-233. https://doi.org/10.1080/10999922.2017.1397999

53. Saputra, I. H., \& Nasrudin. (2015). Pengembangan Model Pendidikan Anti Korupsi Terintegrasi dalam 
Pembelajaran AL-Islam dan Kemuhammadiyahan di Universitas Muhammadiyah Purwokerto. CAKRAWALA, X(1).

54. Sarmini, Made Swanda, I., \& Nadiroh, U. (2018). The importance of anti-corruption education teaching materials for the young generation. Journal of Physics: Conference Series, 953(1). https://doi.org/10.1088/1742-6596/953/1/012167

55. Sarmini, Swanda, I. M., \& Nadiroh, U. (2017). The importance of anti-corruption education teaching materials for the young generation. The 2nd International Joint Conference on Science and Technology (IJCST) 2017. IOP Publishing, 1-5.

56. Sedarmayanti. (2011). Metodologi Penelitian (kedua). CV Mandar Maju.

57. Seto, M. (2019). Anti-Corruption Education in the Millenial Era at PLTEKES Kemenkes. Berumpun Journal: An International Journal of Social, Politics and Humanities, 2(1), 32-39.

58. Sukardi. (2004). Metodologi Penelitian Pendidikan Kompetensi dan Praktiknya. PT. Bumi Aksara.

59. Tanzi, V. (1998). Corruption around the World: Causes, Consequences, Scopes, and Cures (WP/98/63).

60. Ukase, P., \& Audu, B. (2015). The Role of Civil Society in The Fight Against Corruption in Nigeria's Fourth Republic: Problems, Prospects, and The Way Forward. European Scientific Journal, 11(2), 171195.

61. UNODC. (2019). Civil Society for Development Opportunities through the United Nations Convention against Corruption. United Nations. https://www.unodc.org/documents/NGO/Fast-tracking/1806316_eBook.pdf

62. Warren, M. E. (2004). What does Corruption mean in a democracy? American Journal of Political Science, 48(2), 328-343. https://doi.org/10.2307/15119886.

63. Widhiyaastuti, I. G. A. A. D., \& Ariawan, I. G. K. (2018). Meningkatkan Kesadaran Generasi Muda Untuk Berperilaku Anti Koruptif Melalui Pendidikan Anti Korupsi. Acta Comitas, 1, 17-25.

64. Widiastuti, T. W. (2009). Korupsi dan Upaya Pemberantasannya. Wacana, Vol. VIII(No. 2), $107-118$.

65. Yang Pan, T., \& Owen, C. (2013). The Quality Lecture: How Do We Rate? International Journal of Research in Education Methodology, 5(3), 710-720. 